\title{
Robert Mark Wenley, M.A., D.Phil., D.Sc., LL.D.
}

ROBERT Mark Wenley was born in Edinburgh, 19th July 1861, a son of James Adams Wenley, Treasurer of the Bank of Scotland. After graduating M.A. with First Class Honours in Philosophy at Glasgow University, he studied for a period in France, Italy, and Germany. In 1886 he was appointed Assistant to the Professor of Logic in the University of Glasgow, and from 1888 onwards he also acted as Lecturer in Philosophy at Queen Margaret College, the newly instituted college for women. In 1891 he married a daughter of Archibald Gibson, Secretary of the Caledonian Railway Company.

In 1896 he made the critical decision that determined the new and very different field in which the remainder of his life was spent. Accepting a Chair of Philosophy, and the Headship of the Department of Philosophy, in Michigan University, U.S.A., he devoted himself, with his usual wholeheartedness and immense energy, to the interests of his adopted University, and of education generally throughout the State of Michigan. The reputation as a teacher which he had already established in Scotland he maintained to his last years, finding, indeed, more complete expression for his great abilities in his University teaching, and in the practical work of administration in which he took a large share, than in his published writings. The chief fruits of his very active life are, as he would himself, probably, have agreed, to be found in the intellectual interests of the multitudes of students who have passed through his classes in Scotland and in America, and in the outstanding position which Michigan University has won for itself among the State Universities of America. In particular, the University Library-in its admirable arrangements and in its magnificent equipment second only to those of Harvard University Library-was in large part the outcome of his devoted labours.

In 1891 Professor Wenley obtained the D.Sc. from Edinburgh, and in 1901 the Honorary Degree of LL.D. from the University of Glasgow. $\mathrm{He}$ frequently revisited Scotland; and resided in London from 1925 to 1927 as Director of the British Section of the American Universities' Union.

Dr Wenley's chief published works are Socrates and Christ (1889), Aspects of Pessimism (1894), Contemporary Theology and Theism (1897), 
Introduction to Kant (1897), Modern Thought and the Crisis in Belief (Baldwin Lectures, 1909), Kant and his Philosophical Revolution (1910), and numerous articles in the Dictionary of Philosophy and in the Encyclopeedia of Religion and Ethics.

He was elected a Fellow of the Society in 1896, and died in Ann Arbor on 29th March 1929.

N. K. S. 